\title{
Forage Yield and Quality of Chicory, Birdsfoot Trefoil, and Alfalfa During the Establishment Year
}

\author{
Grant Chapman ${ }^{1}$, Edward Bork ${ }^{1}$, Noble Donkor ${ }^{*}, 2$ and Robert Hudson ${ }^{3}$ \\ ${ }^{I}$ Department of Agricultural, Food and Nutritional Science, University of Alberta, Edmonton, AB, T6G 2P5, Canada \\ ${ }^{2}$ Department of Biology, Canadian University College, Lacombe, AB, T4L 2E5, Canada \\ ${ }^{3}$ Department of Renewable Resources, University of Alberta, Edmonton, AB, T6G 2E1, Canada
}

\begin{abstract}
As part of a study to evaluate alternative forages for farmed deer, we compared forage yields and quality of birdsfoot trefoil (Lotus corniculatus) and forage chicory (Cichorium intybus) with that of alfalfa (Medicago sativa) in north central Alberta, Canada. Despite similar plant densities among the three species, the foliar cover of chicory averaged $76 \%, 20 \%$ greater than alfalfa and 50\% greater than trefoil. Alfalfa had higher plant height, dry matter yields, and crude protein concentrations compared to chicory and trefoil, leading to crude protein yields nearly double that of the other forages. Alfalfa also had superior over-winter persistence. Birdsfoot trefoil stands exhibited poor competitiveness in the year of establishment, as demonstrated by high weed and volunteer clover biomass. Chicory had lower neutral detergent fiber concentrations compared to the other forages, leading to a favorable neutral detergent soluble value of $590 \mathrm{~g} \mathrm{~kg}^{-1} \mathrm{DM}, 6 \%$ greater than that of trefoil. In contrast, tannin concentrations were greatest in trefoil (nearly $60 \mathrm{~g} \mathrm{~kg}^{-1} \mathrm{DM}$ ), well above those in the other forages $\left(<20 \mathrm{~g} \mathrm{~kg}^{-1} \mathrm{DM}\right)$. These results highlight the potential of chicory for forage production, as well as the importance of mixing alfalfa with alternative forages to optimize forage yield and quality.
\end{abstract}

Keywords: Alfalfa, birdsfoot trefoil, chicory, quality, sward establishment, yield.

\section{INTRODUCTION}

Game farming systems in the seasonal boreal environments of Canada depend heavily on expensive supplements to meet nutritional needs and maximize deer performance [1]. Feed costs can account for $65 \%$ of livestock production expenses, forcing industry to direct attention at reducing production costs. This is particularly critical for odocoiliene deer (Odocoileus virginianus, Odocoileus hemionus) as their gut morpho-physiology does not make efficient use of conventional grass pastures [1]. Consequently, forage evaluation for increased feeding efficiency, environmental sustainability and reduced production costs has become a priority in aiding development of the deer farming industry in western Canada [2]. Little information exists on the establishment, yield and quality of alternative forage species in northern temperate regions such as the boreal forest, where game farming has been suggested as a viable alternative for livestock producers [3].

The evaluation of novel forages in new growing environments involves assessment of forage establishment, including over-winter survival, and agronomic characterization. Successful establishment includes competitive ability, with persistence over several growing seasons necessary to reduce pasture rejuvenation costs. Traditional agronomic attributes of particular interest to livestock producers include herbage yield and quality throughout the growing season. Given the potential importance of condensed tannins in temperate forages on animal nutrition and productivity $[4,5]$, the

\footnotetext{
*Address correspondence to this author at the Department of Biology, Canadian University College, Lacombe, AB, T4L 2E5, Canada; Tel: 403-7823381, Ext. 4186; E-mail: ndonkor@cauc.ca
}

inclusion of tanniferous plant species in comparative forage trials would be beneficial. The current trial compared the suitability of two alternative forages, birdsfoot trefoil (Lotus corniculatus L. cv 'Leo') and chicory (Cichorium intybus L. cv 'Puna') with alfalfa (Medicago sativa L. cv 'Rangelander') for use as deer pasture in northern Alberta.

Alfalfa is the conventional forage widely used in western Canada, including deer pastures. Although considered highly adapted to Alberta's climate, this forage is low in condensed tannins [6], and contains saponins that may reduce rumen motility [7]. Birdsfoot trefoil is also grown to a limited extent in Alberta, but it is of interest because recent studies indicate it improves dry matter intake and weight gain of red deer (Cervus elaphus) [8]. Chicory, developed in New Zealand for an extensive deer farming industry [9], is relatively new to Canada. Chicory is currently grown throughout much of the United States and may offer a valuable alternative deer forage in western Canada. The specific objectives of this study were to compare the vegetative establishment, herbage yield and quality, and over-winter survival, of chicory, birdsfoot trefoil and alfalfa.

\section{MATERIALS AND METHODS}

\section{Site Description}

A 2-year study (2003 and 2004) was conducted at the Alberta Best Deer Group Ltd. game farm in the Lower Boreal Mixedwood region of north central Alberta $\left(54^{\circ} 42^{\prime}\right.$ $8.7^{\prime \prime} \mathrm{N} ; 113^{\circ} 05^{\prime} 31.7$ ' W). The farm consists of two quarter sections (512 ha) of land, fenced and cross fenced with $2.4 \mathrm{~m}$ tall high tensile page wire. The farm is equipped with a large, well-designed handling facility including many indoor and outdoor dry lot pens and pastures. Prior to this research 
trial, the farm was used for white-tailed deer pasture and hay production, typically with forage stands consisting of alfalfa (Medicago sativa L.), smooth brome (Bromus inermis Leyess), quackgrass (Agropyron repens L.) and alsike clover (Trifolium hybridum L.).

Mean temperatures in the region average $-14.9^{\circ} \mathrm{C}$ and + $16.2^{\circ} \mathrm{C}$ during January and July, respectively. Sixty-percent of annual precipitation falls during the summer growing period (May to August inclusive). During 2003 and 2004, precipitation at the study area was slightly below $(-7 \%)$ and above $(+13 \%)$, respectively, the long-term average of 504 $\mathrm{mm}$. Annual October to May snowfall averages $122 \mathrm{~cm}$. The dominant landform at the study site is a nearly level muskeg floodplain containing soils that are Orthic Gray Luvisols of loam and clay loam texture.

\section{Experimental Procedure}

Seed bed preparation was done in May 2003 using a broadcast application of glyphosate herbicide at a rate of 4.8 $\mathrm{L}^{\mathrm{h}} \mathrm{a}^{-1}$, followed by extensive disking and harrowing. Alfalfa, chicory and birdsfoot trefoil were subsequently seeded with a 3-m wide Brillion forage seeder into plots following a randomized complete block design with seven blocks. Seeding rates were $11.4,12.3$ and $8.9 \mathrm{~kg} \mathrm{ha}^{-1}$ for alfalfa, birdsfoot trefoil and chicory, respectively. Chicory seed was neither inoculated nor fertilized. Both alfalfa and birdsfoot trefoil were inoculated with Noducoat ${ }^{\mathrm{TM}}$ at three times the recommended rate, and coated with a phosphate fertilizer, to protect and keep the rhizobia inoculant viable for a period of six months. The study was repeated in 2004.

\section{Forage Evaluation}

Forage establishment, yield and quality were evaluated in both years in mid August, 69 days after seeding. Over-winter survival of plants seeded the first year was also assessed. In addition, seasonal forage growth was assessed in 2004 only by repeated measurements conducted 3 times during the growing season (25 July, 17 August and 19 September). Dates represent summer and early fall, the period of inherent maximum growth in deer. All data were collected by sampling four, $0.5 \times 1.0 \mathrm{~m}$ randomly placed quadrats within each plot. Average forage sward height, foliar ground cover of seeded plant species, forage plant density and phytomass yield were measured. Yield was obtained by harvesting all standing biomass at a $2-\mathrm{cm}$ height. Samples were sorted to seeded forage, weed and volunteer clover (which emerged from the soil seed bank) components, dried at $60^{\circ} \mathrm{C}$ for $72 \mathrm{~h}$ to determine dry matter (DM), and weighed. The over-winter survival of forages seeded in 2003 was assessed on 17 May, 2004 using ocular estimates of live and dead foliar cover (\%), as well as density counts of live and dead forage plants.

Forage quality was assessed by grinding sub-samples of seeded forage from each plot in a Wiley mill through a 1$\mathrm{mm}$ screen. Crude protein (CP) concentration was determined from nitrogen levels $(\mathrm{CP}=6.25 \mathrm{X} \mathrm{N})$ using a LECO FP-528 nitrogen auto-analyzer [10]. Seeded forage crude protein yield (CPY) levels were also determined for each component $(\mathrm{CPY}=\mathrm{DM}$ yield $\mathrm{X}$ proportional $\mathrm{CP}$ concentration). Neutral detergent fibre (NDF) was determined using the ANKOM filter bag technique [11], and subsequently used to derive neutral detergent soluble (NDS) levels (i.e.,
$100-\mathrm{NDF} \%=$ NDS \%) as well as calculate neutral detergent soluble yield (NDSY) (NDSY = DM yield X proportional NDS concentration). Condensed tannin levels in forages were determined using reversed-phase high-performance liquid chromatography [12].

\section{Statistical Analysis}

Data were subjected to analysis of variance (ANOVA) using PROC Mixed of SAS [13], where seeded forage type, year of establishment, and date of sampling were fixed factors, and forage seeding blocks considered random. Prior to analysis all data were checked for normality through examination of the residuals. Measured response variables included vegetative growth (plant height, cover, density and DM yield), and herbage quality (CP, CPY, NDF, NDS, NDSY and condensed tannins). Repeated measures analysis was utilized in the assessment of seasonal changes in forage agronomic characteristics within each plot during 2004. Where significant main effects or interactions (i.e. between forage type and sampling time) were found, post-hoc comparisons of means were performed using Tukey's method [14], with differences considered significant at $p<0.05$, unless otherwise indicated.

\section{RESULTS}

\section{Forage Establishment and Quality}

Forage height, cover and biomass were affected by forage type $(\mathrm{p}<0.001)$, year of seeding $(\mathrm{p}<0.05)$, and interactions between forage type and year $(p<0.01)$ (ANOVA results not shown). Alfalfa generally produced the tallest forage 69 days after establishment, with birdsfoot trefoil consistently the shortest and chicory similar in height (Table 1). Chicory had the greatest foliar cover, particularly during 2003, while trefoil had less than $40 \%$ ground cover in both years. Alfalfa height and cover responses were also variable between years, a reflection of different precipitation between the two years (Table $\mathbf{1}$ ).

Seeded forage biomass values closely followed the cover responses, being greater for chicory in 2003 than either birdsfoot trefoil or alfalfa (Table 1). In 2004 however, improved alfalfa sward height combined with poorer chicory sward height resulted in similar biomass between these forages, both of which remained greater than trefoil (Table 1). Marked differences in weed and volunteer clover biomass were also observed in plots containing different forage species. Weed biomass in trefoil plots $\left(2141 \mathrm{~kg} \mathrm{ha}^{-1} \mathrm{DM}\right) 69$ days after seeding exceeded $(\mathrm{p}<0.05)$ that found in plots of alfalfa $\left(1070 \mathrm{~kg} \mathrm{ha}^{-1} \mathrm{DM}\right)$ and chicory $\left(656 \mathrm{~kg} \mathrm{ha}^{-1} \mathrm{DM}\right)$ (Fig. 1). Alfalfa plots contained less $(\mathrm{p}<0.05)$ clover than those of chicory and birdsfoot trefoil (Fig. 1).

Comparative forage plant densities also had marked differences between years of establishment. Chicory and birdsfoot trefoil both had high seedling densities in 2003, with the former exceeding that of alfalfa (Table 1). In 2004, plant densities were generally greater for all 3 forages, with similar densities between alfalfa and chicory. Despite the abundance of observed seedlings in 2003, the vast majority of both birdsfoot trefoil (98.3\%) and chicory (90.6\%) plants produced that year experienced over-winter mortality, leading to very low densities of live plants and associated living forage cover the following spring (Fig. 2). In contrast, an 
estimated $71.8 \%$ of alfalfa seedlings survived, leading to greater than $25 \%$ ground cover for this species the following spring. Thus, over-winter live and dead density and cover differed among forages $(\mathrm{P}<0.05)$.

Table 1. Mean (SE in Parentheses) Forage Sward Height, Cover, Plant Density and Dry Matter Yield of Medicago sativa, Lotus corniculatus and Cichorium intybus, 69 Days After Seeding in 2003 and 2004

\begin{tabular}{|l|c|c|}
\hline \multicolumn{1}{|c|}{ Species } & $\mathbf{2 0 0 3}$ & $\mathbf{2 0 0 4}$ \\
\hline \hline \multicolumn{3}{|c|}{ Seeded Forage Sward Height (cm) } \\
\hline Medicago sativa & $25(1.5) \mathrm{a}^{\mathrm{z}}$ & $46(1.4) \mathrm{a}$ \\
\hline Lotus corniculatus & $18(1.4) \mathrm{b}$ & $25(1.3) \mathrm{b}$ \\
\hline Cichocorium intybus & $21(1.4) \mathrm{ab}$ & $28(1.3) \mathrm{b}$ \\
\hline \multicolumn{3}{|c|}{ Seeded Forage Cover (\%) } \\
\hline Medicago sativa & $42(5.6) \mathrm{b}$ & $73(4.7) \mathrm{a}$ \\
\hline Lotus corniculatus & $37(5.1) \mathrm{b}$ & $39(4.7) \mathrm{b}$ \\
\hline Cichocorium intybus & $77.6(5.1) \mathrm{a}$ & $75(4.7) \mathrm{a}$ \\
\hline \multicolumn{3}{|c|}{ Seeded Forage Plant Density (number $\left.\mathbf{m}^{-2}\right)$} \\
\hline Medicago sativa & $90(29) \mathrm{b}$ & $257(24) \mathrm{a}$ \\
\hline Lotus corniculatus & $136(27) \mathrm{a}$ & $224(24) \mathrm{b}$ \\
\hline Cichocorium intybus & $110(27) \mathrm{ab}$ & $256(24) \mathrm{a}$ \\
\hline \multicolumn{3}{|c|}{ Seeded Forage Dry Matter Yield (kg ha-1 DM) } \\
\hline Medicago sativa & $1363(215) \mathrm{b}$ & $1701(183) \mathrm{a}$ \\
\hline Lotus corniculatus & $1227(215) \mathrm{b}$ & $498(183) \mathrm{b}$ \\
\hline Cichocorium intybus & $1924(197) \mathrm{a}$ & $1350(183) \mathrm{a}$ \\
\hline
\end{tabular}

${ }^{\mathrm{z}}$ Within a column and variable, means with different lower case letters differ significantly, $\mathrm{P}<0.05$.

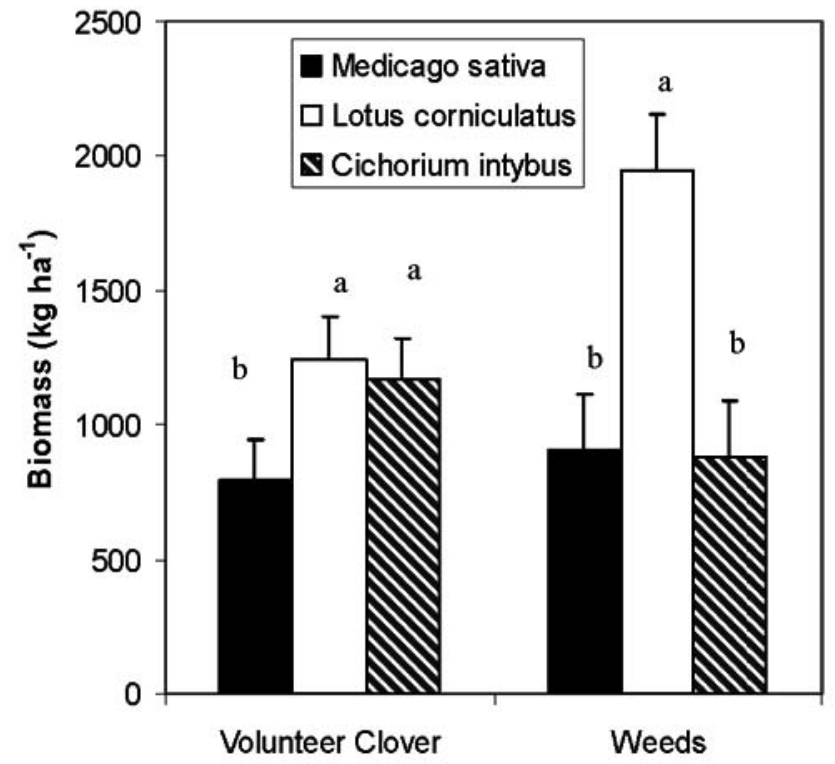

Fig. (1). Mean (with SE bars) standing biomass of volunteer clover and weeds within forage stands seeded to each of 3 species in both years. Means with different letters within a component differ, $\mathrm{p}<0.05$.
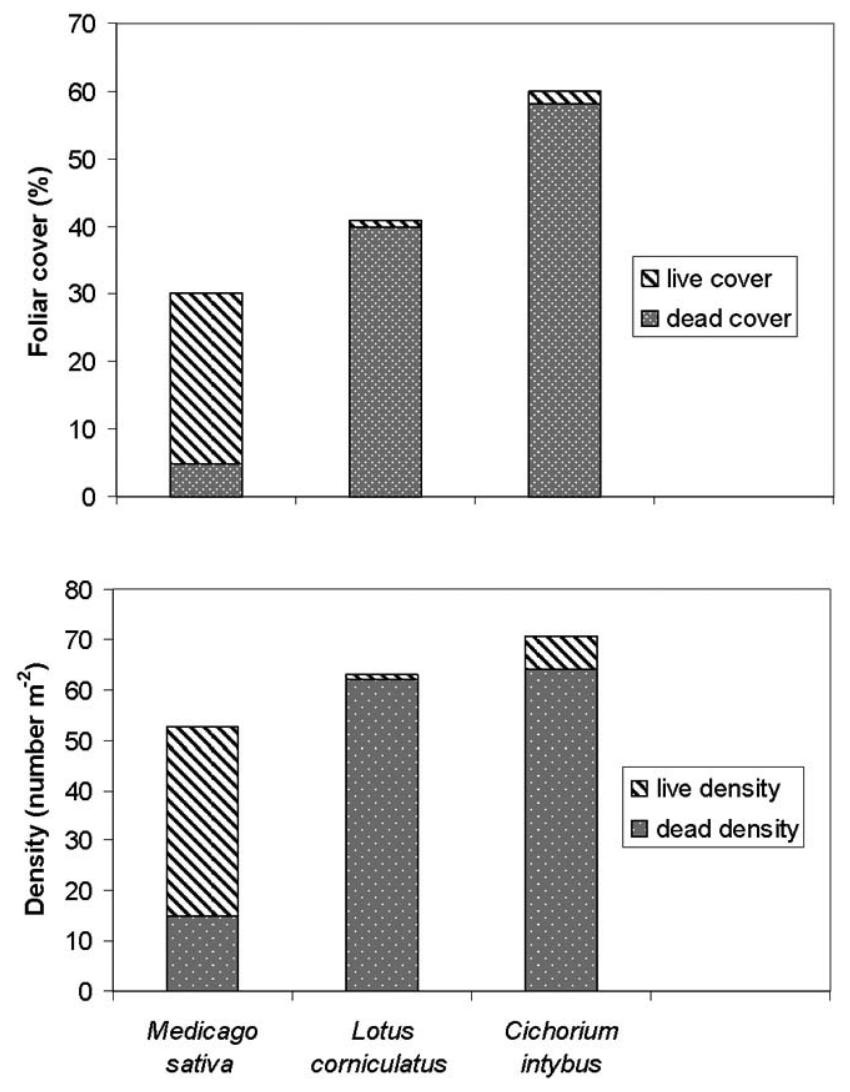

Fig. (2). Over-winter survival in May 2004 of forages seeded in 2003. Live and dead density and cover differed among forages $(\mathrm{P}<$ $0.05)$.

During both years of the study, crude protein (CP) concentrations associated with newly established alfalfa were 5$6 \%$ higher than those in the other two forages when estimated at the common sampling date (Table 2). Neutral detergent soluble (NDS) levels were examined only in 2004, when they were $6 \%$ greater in chicory than birdsfoot trefoil (Table 2). Condensed tannin concentrations were much greater in young swards of trefoil (nearly $60 \mathrm{~g} \mathrm{~kg}^{-1} \mathrm{DM}$ ) compared to both of the other forages $\left(<20 \mathrm{~g} \mathrm{~kg}^{-1} \mathrm{DM}\right)$ in each year of establishment (Table 2). Tannin concentrations in chicory remained above those of alfalfa in 2003, but were similar to alfalfa in 2004.

\section{Seasonal Forage Dynamics}

Within seasonal growth variation among the three species is given in Table 3. Chicory reached peak biomass the earliest (i.e., by late July), with only minimal gains in biomass thereafter (Table 3). Alfalfa continued to increase in biomass through mid August, after which biomass remained unchanged. In contrast, birdsfoot trefoil had very slow establishment relative to the other 2 species in 2004, but increased in biomass through to late September (Table 3).

As expected, crude protein levels progressively declined from July through September, although no strong within season differences in $\mathrm{CP}$ concentrations were evident among forages. Overall, mean year-long alfalfa $\mathrm{CP}$ remained greater than $\mathrm{CP}$ values in trefoil (Table 3). Unlike CP, neutral detergent fiber concentrations had distinct seasonal differences 
Table 2. Mean (SE in Parentheses) Chemical Measures of Forage Quality in Medicago sativa, Lotus corniculatus and Cichorium intybus, 69 Days After Seeding in 2003 and 2004

\begin{tabular}{|l|c|c|}
\hline \multicolumn{1}{|c|}{ Species } & $\mathbf{2 0 0 3}$ & $\mathbf{2 0 0 4}$ \\
\hline \hline \multicolumn{2}{|c|}{ Seeded Forage Crude Protein $\left(\mathbf{g ~ k g}^{-1} \mathbf{~ D M}\right)$} \\
\hline Medicago sativa & $213(16) \mathrm{a}^{\mathrm{z}}$ & $196(14) \mathrm{a}$ \\
\hline Lotus corniculatus & $146(15) \mathrm{b}$ & $146(14) \mathrm{b}$ \\
\hline Cichocorium intybus & $144(15) \mathrm{b}$ & $166(14) \mathrm{b}$ \\
\hline \multicolumn{3}{|c|}{ Seeded Forage Neutral Detergent Soluble $\left(\mathbf{g ~ k g}^{-1} \mathbf{D M}\right)$} \\
\hline Medicago sativa & $\mathrm{n} / \mathrm{a}$ & $551(15) \mathrm{ab}$ \\
\hline Lotus corniculatus & $\mathrm{n} / \mathrm{a}$ & $531(15) \mathrm{b}$ \\
\hline Cichocorium intybus & $\mathrm{n} / \mathrm{a}$ & $592(16) \mathrm{a}$ \\
\hline \multicolumn{3}{|c|}{ Condensed Tannins $\left(\mathbf{g ~ k g} \mathbf{~}^{-1} \mathbf{D M}\right)$} \\
\hline Medicago sativa & $5.3(4.2) \mathrm{c}$ & $3.4(2.6) \mathrm{b}$ \\
\hline Lotus corniculatus & $66.9(4.2) \mathrm{a}$ & $51.7(2.6) \mathrm{a}$ \\
\hline Cichocorium intybus & $20(4.2) \mathrm{b}$ & $3.6(1.5) \mathrm{b}$ \\
\hline
\end{tabular}

${ }^{2}$ Within a column and variable, means with different lower case letters differ significantly, $\mathrm{P}<0.05$.

among forage types. Chicory had lower $(\mathrm{p}<0.05)$ NDF values compared to both birdsfoot trefoil and alfalfa, a trend that remained consistent at each of the 3 sampling times (Table 3). While alfalfa followed the predictable pattern of increasing NDF in early fall with advancing senescence, birdsfoot trefoil NDF remained largely unchanged, and chicory unexpectedly declined in NDF during late summer and early fall (Table 3).

Table 3. Seasonal Changes in Mean (SE in Parentheses) Standing Biomass, Crude Protein and Neutral Detergent Fiber of Newly Established Seeded Forages as Sampled in July, August and September of 2004

\begin{tabular}{|c|c|c|c|}
\hline Month & Medicago sativa & Lotus corniculatus & Cichorium intybus \\
\hline \multicolumn{4}{|c|}{ Seeded Forage Biomass $\left(\mathrm{kg} \mathrm{ha}^{-1} \mathrm{DM}\right)$} \\
\hline Jul-25 & $\mathrm{B}^{\mathrm{z}} 1701(275) \mathrm{a}^{\mathrm{y}}$ & B $498(275) c$ & A $1351(275) b$ \\
\hline Aug-17 & A $3339(460)$ a & $\mathrm{AB} 1009(460) \mathrm{b}$ & A $1562(460)$ b \\
\hline Sep-19 & A $3361(447)$ a & A $1601(447)$ b & A 1904 (447) b \\
\hline All Times & $2800(330)$ a & $1026(330) \mathrm{b}$ & $1606(330) \mathrm{b}$ \\
\hline \multicolumn{4}{|c|}{ Seeded Forage Crude Protein $\left(\mathrm{g} \mathrm{kg}^{-1} \mathrm{DM}\right)$} \\
\hline Jul-25 & $196(16) \mathrm{a}$ & $146(16) b$ & $166(16) a b$ \\
\hline Aug-17 & $161(13) \mathrm{a}$ & $119(13) \mathrm{b}$ & $142(13) a b$ \\
\hline Sep-19 & $129(7) \mathrm{a}$ & $117(7) \mathrm{a}$ & $114(7) \mathrm{a}$ \\
\hline All Times & $162(10) \mathrm{a}$ & $127(10) b$ & $141(10) a b$ \\
\hline \multicolumn{4}{|c|}{ Seeded Forage Neutral Detergent Fiber $\left(\mathrm{g} \mathrm{kg}^{-1} \mathrm{DM}\right)$} \\
\hline Jul-25 & B 449 (13) ab & A $469(13)$ a & A 409 (13) b \\
\hline Aug-17 & B 453 (15) a & A 437 (15) a & C 305 (15) b \\
\hline Sep-19 & A $520(13)$ a & A 493 (13) a & B 366 (13) b \\
\hline All Times & 474 (8) a & 466 (8) a & $360(8) b$ \\
\hline
\end{tabular}

${ }^{2}$ Within a column and variable, means with different uppercase letters are significantly different $(\mathrm{p}<0.05)$.

${ }^{y}$ Within a row, means with different lowercase letters are significantly different $(\mathrm{p}<0.05)$.
Forage biomass and quality data were combined to evaluate crude protein yield (CPY) and neutral detergent soluble yield (NSDY). No differences were evident in seasonal CPY values among forage species (data not shown), with the season-long mean CPY of alfalfa $\left(375 \mathrm{~kg} \mathrm{ha}^{-1} \mathrm{DM}\right)$ greater $(\mathrm{p}<0.05)$ than that in chicory $\left(190 \mathrm{~kg} \mathrm{ha}^{-1} \mathrm{DM}\right)$ and trefoil (174 $\left.\mathrm{kg} \mathrm{ha}^{-1} \mathrm{DM}\right)$. A parallel pattern was evident with NDSY, with mean alfalfa (1303 kg ha ${ }^{-1}$ DM) NDSY markedly greater $(\mathrm{p}<0.05)$ than that in either chicory $\left(901 \mathrm{~kg} \mathrm{ha}^{-1}\right.$ DM) or trefoil $\left(640 \mathrm{~kg} \mathrm{ha}^{-1} \mathrm{DM}\right)$.

\section{DISCUSSION}

\section{Forage Establishment}

In our study location, chicory established rapidly, producing plant densities and cover similar to or greater than that of alfalfa depending on the year of establishment, and led to good competitive ability against weeds. These results are consistent with the findings of a study in central Pennsylvania where chicory developed three to four leaves and a root system capable of supporting this leaf mass by as little as 40 to 50 days after planting [15]. Evaluations of chicory suitability in northern climates of Canada prior to this study have been limited to Atlantic Canada [16]. Although that study found acceptable persistence of chicory after 3 years, and reported observations of naturalized chicory plants in the region, those results are in sharp contrast to the near complete failure of stand persistence in the present investigation. Instead, our results are more consistent with research in Pennsylvania [17] and New Zealand [18] where chicory stand losses after 1 year were as high as $50 \%$ and $33 \%$, respectively, and up to $75 \%$ by year 4 with a $50 \%$ reduction in biomass [19].

Although we did not directly evaluate mechanisms accounting for chicory stand failure, we hypothesize that winter temperatures may have played an important role. January mean temperatures in our study area were $-17.2^{\circ} \mathrm{C}$, a full $5.2^{\circ} \mathrm{C}$ colder than the Atlantic Canada study, and $11.6^{\circ} \mathrm{C}$ colder than another Pennsylvanian study where winterkill estimates were $30 \%$ after one year [20]. A recent unpublished study from southern Alberta near the town of Brooks, more than $400 \mathrm{~km}$ south of the present study site and demonstrating a milder climate (mean January temp of $-11.3^{\circ} \mathrm{C}$ ), reported good winter survival of chicory varieties originating from Europe (Bandara M, unpublished data). However, even under optimal management, stand persistence of chicory is a maximum of 4 years [21].

Our attempts to establish an acceptable stand of birsdfoot trefoil were limited in each of two seasons. Despite having favourable stand densities early on, trefoil height, cover and yield remained well below that of the other species. Birdsfoot trefoil is considered difficult to establish as it has a small seed size, low seedling vigor, late maturity, and as a result, is a poor competitor [22, 23], which likely accounts for the gradual biomass increases and high associated weed and volunteer clover biomass levels we observed in developing swards of this species. Intense competition and poor establishment appeared to result in less vigorous plants, potentially contributing to the high observed winterkill, with other studies in milder climates reporting winter kill after one year to be $65 \%$ and $69 \%[24,25]$. Hall [26] found that the inclusion of small grain companion crops at seeding reduced tre- 
foil root development, seedling vigor, stand density and biomass.

Birdsfoot trefoil is considered a valuable forage with more than 1 million ha seeded in the United States [27], but presently is not a widely used legume in Alberta because of problems in stand persistence [23], a shortfall corroborated by the current study. Although birdsfoot trefoil is recommended as suitable pasture forage by the Alberta, Saskatchewan and Manitoba departments of agriculture for climates and soil zones similar to our study region if managed carefully, our results suggest this may be more problematic than previously thought.

\section{Forage Yield}

Our observations of chicory yield in northern Alberta (1904 kg ha $\left.{ }^{-1} \mathrm{DM}\right)$ are much greater than those from Atlantic Canada, where chicory produced $985 \mathrm{~kg} \mathrm{ha}^{-1} \mathrm{DM}$ and 687 $\mathrm{kgha}^{-1} \mathrm{DM}$ in years one and three, respectively [16]. However, our yields remained well below those from the northeastern United States, where chicory yields ranged from 6028 to $7200 \mathrm{~kg} \mathrm{ha}^{-1} \mathrm{DM} 1$ [28, 17], and $9640 \mathrm{kgha}^{-1} \mathrm{DM}$ reported from New Zealand [19]. Wilson et al. [29], reported root yields alone for chicory of 3600 to $5500 \mathrm{~kg} \mathrm{ha}^{-1} \mathrm{DM}$ in Nebraska. Our chicory yields were also well below those from southern Alberta where chicory $\left(6400 \mathrm{kgha}^{-1} \mathrm{DM}\right)$ outyielded corn silage crops (Bandara $\mathrm{M}$, unpublished data). However, the latter study was conducted under intensively managed and irrigated conditions on Dark Brown Chernozem soils, conditions markedly different from the northern temperate Boreal environments examined here. Differences in observed chicory yields can be attributed to variation in soil quality and growing season length, together with heavy fertilization and irrigation.

Low season-long yields of birdsfoot trefoil compared with other legumes can be attributed to its slow growth and reliance on photo-assimilates rather than stored nonstructural carbohydrates [30]. Our biomass levels remained below that of first year yields from other regions of Canada, where trefoil biomass ranged from 4900 to $5989 \mathrm{~kg} \mathrm{ha}^{-1} \mathrm{DM}$ $[31,32]$. Other studies from western Canada have found yields from $3250 \mathrm{~kg} \mathrm{ha}^{-1} \mathrm{DM}$ to $6299 \mathrm{~kg} \mathrm{ha}^{-1} \mathrm{DM}$ (e.g. [33]. The low biomass in the current study may be an indication that the agro-climatic region near Athabasca was poorly suited for birdsfoot trefoil, particularly when coupled with the loss in yield due to competition from other vegetation. Similar to chicory, birdsfoot trefoil has no means of vegetative reproduction, leading to reductions in stand density over time, especially in highly stressed environments or grazing systems $[34,18]$.

Alfalfa was included in this trial as a common pasture forage for deer in Alberta with many varieties available that are adapted to various regions of Canada. Average biomass yields for the Athabasca area for alfalfa in established stands is $5753 \mathrm{~kg} \mathrm{ha}^{-1} \mathrm{DM}$ [22], which is greater than our first year maximal yields of $3361 \mathrm{~kg} \mathrm{ha}^{-1} \mathrm{DM}$. Nevertheless, the alfalfa yields were as high as or greater than that of the other forages, and peaked quickly following seeding, highlighting the agronomic value of this species.

\section{Forage Quality}

The evaluation of alternative forages, specifically those containing secondary compounds for improving productivity in grazing ruminants, has recently been reviewed by Ramirez-Restrepo and Barry [34]. This review included an evaluation of chicory, birdsfoot trefoil, sulla (Hedysarum coronarium), alfalfa, white and red clover (Trifolium pratense and Trifolium repens), and perennial ryegrass (Lolium perenne), and concluded that the greatest advantages were offered by chicory, sulla, and the condensed tannin containing leguminous species birdsfoot trefoil.

The current study's findings on chicory protein, neutral detergent fiber, tannin concentrations and seasonal growth patterns, are consistent with the literature indicating this species can provide adequate quality forage for deer pasture throughout the summer (CP [35], NDF [36], condensed tannins [37, 38]. The decline in chicory NDF from an initial high in July, into August and September, led to greater digestibility in this species compared to the other forages in late summer and fall. This finding suggests chicory may be useful for extending the grazing season, which would be an important benefit in improving animal performance including preparation for winter.

While it is accepted that birdsfoot trefoil has several negative concerns associated with its use, it does have several benefits arising from its favorable forage quality. Birdsfoot trefoil crude protein and NDF concentrations found here were consistent with the literature $[39,33]$, as the protein concentration contributed positively to crude protein yields. Additionally, condensed tannin concentrations in trefoil were much greater than in the other two forages examined. While tannin levels in trefoil can vary from as low as $23 \mathrm{~g} \mathrm{~kg}^{-1} \mathrm{DM}$ to $110 \mathrm{~g} \mathrm{~kg}^{-1} \mathrm{DM}$, with concentrations lowest in unstressed, monoculture stands [39, 40], variance in tannin levels throughout the growing season is common [41]. The availability of birdsfoot trefoil could provide beneficial nutritional effects because the tannin levels required to control bloat and increase amino acid absorption are $5 \mathrm{~g} \mathrm{~kg}^{-1}$ DM and 30-40 $\mathrm{g} \mathrm{kg}^{-1}$ DM, respectively $[42,33]$.

Although alfalfa digestibility was below that of chicory, alfalfa crude protein was very high, consistent with the recommendation of including alfalfa to increase forage quality of pasture [43]. Alfalfa is currently recommended as the first choice legume to seed for deer pasture in western Canada, with many studies and observations confirming that alfalfa is highly palatable to white-tailed deer when plants are vegetative and/or actively growing [44]. The greater yields of alfalfa compared to chicory and birdsfoot trefoil, coupled with high over-winter survival, suggests that this species should remain the primary forage of choice for deer production in northern Alberta.

\section{CONCLUSIONS}

Forage suitability evaluations in the northern climate of western Canada revealed valuable information regarding forage establishment, yield, quality and stand persistence of chicory, birdsfoot trefoil, and alfalfa as deer forage. Chicory established quickly producing a competitive sward, was high 
in quality and low in tannin, but did not over-winter well in northern Alberta. Therefore, while useful as annual forage, it may not be suitable for perennial pasture in this region unless winter hardiness can be enhanced. Although birdsfoot trefoil had good forage quality including tannin levels, it had slow establishment, was a weak competitor against weeds, and had poor over-winter persistence. Although demonstrating select positive attributes, both chicory and birdsfoot trefoil were generally inferior to alfalfa, which established well, produced abundant high quality forage, and had superior over-winter survival. Mixtures of alfalfa with other forages, particularly chicory, may prove beneficial for short-term deer production in northern climates.

\section{ACKNOWLEDGEMENTS}

Financial support was provided by the Alberta Agricultural Research Institute (Project 2003A061R) and the Natural Sciences and Engineering Research Council of Canada. Other support is acknowledged from the Departments of Renewable Resources and Agricultural, Food and Nutritional Science at the University of Alberta. We appreciate the assistance of Alberta Best Deer Group Ltd. for accommodating our study and providing in-kind support.

\section{REFERENCES}

[1] Hudson RJ, Irving B, Gedir J, Donkor N, Swanson K, Morley F. Nutrition of farmed white-tailed and mule deer. Project completion report. AARI direct funding project 990013. University of Alberta, Edmonton 2000; p. 36.

[2] Alberta Agriculture, Alberta Agricultural Research Institute. 500 Phipps-McKinnon Building 10020 - 101 A Avenue. Edmonton, Alberta T5J 3G2 2003.

[3] Telfer ES, Scotter GW. Potential for game ranching in boreal aspen forests of western. Can J Range Manage 1975; 28: 172-80.

[4] Barry TN, McNabb WC. The implications of condensed tannins on the nutritive value of temperate forages fed to ruminants. Br J Nutr 1999; 81: 248-54.

[5] Min BR, Barry TN, Attwood GT, McNabb WC. The effect of condensed tannins on the nutrition and health of ruminants fed fresh temperate forages: a review. Anim Feed Sci Technol 2003; 106: 3-19.

[6] Mould ED, Robbins CT. Digestive capabilities in elk compared to white-tailed deer. J Wildl Manage 1982; 46: 22-9.

[7] Francis G, Kerem Z, Makkar HPS, Becker K. The biological action of saponins in animal systems: a review. Br J Nutr 2002; 88: 587605 .

[8] Adu EK, Barry TN, Wilson PR, Kemp PD. Evaluation of Lotus corniculatus for increasing pre-weaning growth of red and hybrid deer. J Agric Sci 1998; 131: 237-43.

[9] Moloney SC, Milne GD. Establishment and management of grasslands Puna chicory used as a specialist, high quality forage pasture. Proc NZ Grassl Assoc 1993; 55: 113-8.

[10] Association of Analytical Chemists. AOAC official method 990.03 Protein by nitrogen gas analyzer utilizing induction furnace and thermal conductivity (LECO FP-528). Official methods of analysis of AOAC international, $16^{\text {th }}$ ed, International, Gaithersburg, MD 1995.

[11] Komarek AR. An improved filtering technique for the analysis of neutral detergent fiber and acid detergent fiber utilizing the filter bag technique. Ackom Co., Fairport, NY 1993.

[12] Koupai-Abyazani MR, McCallum J, Bohm BA. Identification of the constituent flavonoid units in sainfoin proanthocyanidins by reversed-phase high-performance liquid chromatography. J Chromatogr 1992; 594: 117-23.

[13] Statistical Analysis Software. SAS Institute Inc version 9.1. Cary, NC, USA 275132002.

[14] Steel R, Torrie J, Dickey D. Principles and Procedures of Statistics: A Biometrical Approach, McGraw-Hill, New York, NY 1997.

[15] Sanderson MA, Elwinger GF. Seedling development of Chicory and Plantain. Agron J 2000; 92: 69-74.
[16] Kunelius HT, McRae KB. Forage chicory persists in combination with cool season grasses and legumes. Can J Plant Sci 1998; 79: 179-200.

[17] Labreveux M, Hall MH, Sanderson MA. Productivity of chicory and plantain cultivars under grazing. Agron J 2004; 96: 710-6.

[18] Li GD, Kemp PD, Hodgson J. Regrowth, morphology, and persistence of Grasslands Puna chicory (Cichorium intybus L.) in response to grazing frequency and intensity. Grass Forage Sci 1997; 52: 33-41.

[19] Li GD, Kemp PD, Hodgson J. Herbage production and persistence of Puna chicory (Cichorium intybus L.) under grazing management over 4 years. N Z J Agric Res 1997; 40: 51-6.

[20] Skinner HR, Gustine DL. Freezing tolerance of chicory and narroleaf plantain. Crop Sci 2002; 42: 2038-43.

[21] Barry TN. The feeding value of chicory (Cichorium intybus) for ruminant livestock. J Agric Sci Cambridge 1998; 131: 251-7.

[22] Manitoba Agriculture and Food. Manitoba Agriculture, Food and Rural Initiatives Variety Guide. [Cited 2007 July 21]. Available from: http://www.gov.mb.ca/agriculture/crops/pdf/seed 2007/forag es.pdf

[23] Alberta Agriculture and Food. Bird's-Foot Trefoil Yield Comparisons. [cited 2007 July 20]. Available from: http://www1.agric.gov. ab.ca/\$Department /deptdocs.nsf/all/ for4096

[24] McKenzie DB, Papadopoulos YA, McRae KB. Harvest management affects yield and persistence of birdsfoot trefoil (Lotus corniculatus L.) in cool summer climates. Can J Plant Sci 2004; 84: 5258.

[25] Brummer EC, Moore KJ. Persistence of perennial cool-season grass and legume cultivars under continuous grazing by beef cattle. Agron J 2000; 92: 466-71

[26] Hall MH. Birdsfoot trefoil: Agronomy Facts 20. College of Agricultural Science, Cooperative Extension. The Pennsylvania State University, 201 Willard Building, University Park, PA 2007; 16802-2801.

[27] Beuselinck PR, Grant WF. Birdsfoot trefoil. In: Barnes RF, Miller DA, Nelson CJ, Eds. Forages: An introduction to grassland agriculture, Iowa State University Press, Ames Iowa 1995; vol. 1: pp. 23748.

[28] Sanderson MA, Labreveux M, Hall MH, Elwinger GF. Forage yield and persistence of chicory and English plantain. Crop Sci 2003; 43: 995-1000.

[29] Wilson RG, Smith JA, Yonts CD. Chicory root yield and carbohydrate composition is influenced by cultivar selection, planting, and harvest date. Crop Sci 2004; 44: 748-52.

[30] McGraw RL, Martin GC. Analysis of primary spring growth of four pasture legume species. Agron J 1986; 78: 704-10.

[31] McKenzie DB, Papadopoulos YA, McRae KB. Harvest management affects yield and persistence of birdsfoot trefoil (Lotus corniculatus L.) in cool summer climates. Can J Plant Sci 2004; 84: 5258.

[32] Cassida KA, Griffin TS, Rodriguez J, Patching SC, Hesterman OB, Rust SR. Protein degradability and forage quality in maturing alfalfa, red clover, and birdsfoot trefoil. Crop Sci 2000; 40: 209-15.

[33] Saskatchewan Agriculture and Food. 2006. Saskatchewan Forage crop production guide. [cited 2007 July 21]. Available from: http://www.agr.gov.sk.ca/docs/production/forageguide07revised. pdf

[34] Ramirez-Restrepo CA, Barry TN. Alternative temperate forages containing secondary compounds for improving sustainable productivity in grazing ruminants. Anim Feed Sci Technol 2005; 120: 179-201.

[35] Foster JG, Fedders JM, Clapham WM, Robertson JW, Bligh DP, Turner KE. Nutritive value and animal selection of forage chicory cultivars grown in central appalachia. Agric J 2002; 94: 1034-42.

[36] Turner KE, Belesky DP, Fedders JM. Chicory effects on lamb weight gain and rate of in vitro organic matter and fiber disappearance. Agron J 1999; 91: 445-50.

[37] Jung GA, Shaffer JA, Varga GA, Everhart JR. Perforamnce of "Grasslands Puna" chicory at different management levels. Agron J 1996; 88: 104-11.

[38] Schreurs NM, Molan AN, Lopez-Villalobos N, Barry TN, McNabb WC. Effects of grazing undrenched weaner deer on chicory or perennial ryegrass/white clover pasture on the viability of gastrointestinal nematodes and lungworms. Vet Rec 2002; 151: 348-53.

[39] Waghorn GC, Tavendale MH, Woodfield DR. Methanogenesis from forages fed to sheep. Proc NZ Grassl Assoc 2002; 64:159-65. 
[40] Gebrehiwot L, Beuselinck PR, Roberts CA. Seasonal variations in condensed tannin concentration of three Lotus species. Agron $\mathbf{J}$ 2002; 94: 1059-65.

[41] Wen L, Roberts CA, Wiliiams JE, Kallenbach RL, Beuselinck PR, McGraw RL. Condensed tannin concentration of rhizomatous and nonrhizomatous birdsfoot trefoil in grazed mixtures and monocultures. Crop Sci 2003; 43: 302-6.
[42] Aerts RJ, Barry TN, McNabb WC. Polyphenols and agriculture: beneficial effects of proanthocyanidins in forages. Agric Ecosyst Environ 1999; 75: 1-12.

[43] Barnes DK, Sceaffer CC. Alfalfa. In: Barnes RF, Miller DA, Nelson CJ, Eds. Forages: An introduction to grassland agriculture. Iowa State University Press, Ames Iowa 1995; vol. 1: pp. 205-15.

[44] Grazing and Pasture Technology Program, Pasture and forage for white-tailed deer. Box 4752, Regina, Saskatchewan, S4P 3Y4, 1999.

(c) Chapman et al.; Licensee Bentham Open.

This is an open access article licensed under the terms of the Creative Commons Attribution Non-Commercial License (http://creativecommons.org/licenses/bync/3.0/) which permits unrestricted, non-commercial use, distribution and reproduction in any medium, provided the work is properly cited. 